Bond University

Research Repository

\title{
Survivorship bias and alternative explanations of momentum effect
}

Henker, Julia; Henker, Thomas; Huynh, Thanh Duc

Published in:

Proceedings of the 2011 FMA Annual Meeting

Licence:

CC BY-NC-ND

Link to output in Bond University research repository.

Recommended citation(APA):

Henker, J., Henker, T., \& Huynh, T. D. (2011). Survivorship bias and alternative explanations of momentum effect. In J. Kose (Ed.), Proceedings of the 2011 FMA Annual Meeting (pp. 1-43). Financial Management Association .

\section{General rights}

Copyright and moral rights for the publications made accessible in the public portal are retained by the authors and/or other copyright owners and it is a condition of accessing publications that users recognise and abide by the legal requirements associated with these rights.

For more information, or if you believe that this document breaches copyright, please contact the Bond University research repository coordinator. 


\section{Bond University}

\section{ePublications@bond}

$10-19-2011$

\section{Survivorship bias and alternative explanations of momentum effect}

Julia Henker

Bond University, julia_henker@bond.edu.au

Thomas Henker

Bond University, Thomas_Henker@bond.edu.au

Thanh Duc Huynh

Queensland University of Technology

Follow this and additional works at: http://epublications.bond.edu.au/business_pubs

Part of the Finance and Financial Management Commons

\section{Recommended Citation}

Julia Henker, Thomas Henker, and Thanh Duc Huynh. (2011) "Survivorship bias and alternative explanations of momentum effect" 2011 Financial Management Association (FMA) Annual Meeting. Denver, Colorado, United States.Oct. 2011.

http://epublications.bond.edu.au/business_pubs/530

This Conference Paper is brought to you by the Bond Business School at ePublications@bond. It has been accepted for inclusion in Bond Business School Publications by an authorized administrator of ePublications@bond. For more information, please contact Bond University's Repository 


\title{
Survivorship Bias and Alternative Explanations of Momentum Effect
}

\author{
Julia Henker, Thomas Henker and Thanh Duc Huynh*
}

This version: 27 September August, 2010

This paper provides the first detailed examination of momentum effect in Australian equity market. In contrast to previous research, we find that momentum effect has not been present in Australian market since late 1970s. We argue that previous research found strong momentum effect because they assumed perfect foresight of future delisting or acquisitions in the sampling process. In addition, we find that Fama and French three-factor model cannot explain the mean momentum returns although it can fully rationalize the returns on winners and losers portfolios. Our findings raise awareness in the literature that momentum effect is not robust to different sampling methods. We contribute an alternative explanation to momentum returns documented in existing literature. Momentum effect could be a product of look-ahead bias incurring from the sampling techniques. More importantly, we provide supports to the efficient market hypothesis at weak form. KEYWORDS: MOMENTUM PORTFOLIOS, ABNORMAL RETURNS PORTFOLIO
SELECTIONFACTOR RETURNS

* Julia Henker and Thomas Henker are from Bond University, Robina QLD 4229, Australia. Thanh Duc Huynh is from School of Economics and Finance, Queensland University of Technology, Brisbane QLD 4000. Corresponding author: Thomas Henker, tel: +61 7 5595-1561, fax: +61 2 9385-6347, e-mail: thenker@bond.edu.au. We thank Peter Pham for generously supplying some data for this study. The usual disclaimer applies. 


\begin{abstract}
This paper provides the first detailed examination of momentum effect in Australian equity market. In contrast to previous research, we find that momentum effect has not been present in Australian market since late 1970s. We argue that previous research found strong momentum effect because they assumed perfect foresight of future delisting or acquisitions in the sampling process. In addition, we find that Fama and French three-factor model cannot explain the mean momentum returns although it can fully rationalize the returns on winners and losers portfolios. Our findings raise awareness in the literature that momentum effect is not robust to different sampling methods. We contribute an alternative explanation to momentum returns documented in existing literature. Momentum effect could be a product of look-ahead bias incurring from the sampling techniques. More importantly, we provide supports to the efficient market hypothesis at weak form.
\end{abstract}

\title{
1. Introduction
}

It is believed that in an efficient market, prices fully and instantaneously reflect all available relevant information. This means that investors cannot earn abnormal profits based on the information that is publicly known to the market including historical prices. However, the efficient market hypotheses have been challenged by a simple trading strategy called momentum. Momentum strategies buy the best performing stocks over the past three to twelve months and sell the worst performing stocks over the same period. The investment strategies appear to be simple but consistently profitable both economically and statistically in several equity markets.

The presence of momentum effect is unpleasant evidence against market efficiency. Several noticeable explanations for the momentum effect are behavioral theories, risk-based 
models and even the attack of "data snooping". The evidence is so robust that believers in efficient markets are not able to explain. For this reason, it is not unexpected that the momentum literature has rapidly grown to be one of the most controversial and contemporary topics in modern finance.

Since the seminal publication of Jegadeesh and Titman (1993) documented a significant momentum profit in United States (US) equity markets, there has been a growing body of literature showing that the momentum effect is also present across international markets outside the US (Rouwenhorst, 1998; Griffin et al., 2003 and Chui et al., 2000, 2010). However, a market that stands out from the crowd is the Australian Stock Exchange (ASX) where the presence of the momentum effect has not gained consensus in the literature. Given that the Australian market is small enough to be an out-of-sample test but large enough to attract interests of researchers and practitioners, it is surprising that momentum studies in Australia are limited in terms of quantity and scope.

This paper contributes to the literature in several ways. Firstly, it is the first to examine the impact of survivorship bias on the findings of momentum effect. Previous research either assumes "perfect foresight" of future delisting or acquisitions (e.g. Grundy and Martin, 2001, Demir et al., 2004 and Galariotis, 2010) or does not mention solutions to such bias. To explore this impact, we follow the methodology of Henker et al. (2006) to realistically relax the perfectforesight assumption. We find no evidence of momentum effect in the ASX from 1977 to 2008. We are able to replicate previous studies with the look-ahead assumption in place and produce comparable momentum returns. This leads us to argue that momentum effect is not robust to different sampling methods and the survivorship bias may cause significant momentum profits documented in the literature. Secondly, we examine the explanatory power of Fama and French 
(1993) three-factor model on momentum returns. We construct the Fama-French three factors from a large sample which covers $86 \%$ of ASX listed stocks from 1993 to 2008. This allows us to produce a detailed and robust examination of Fama and French three-factor model in Australia that is comparable to overseas findings. Finally, this study examines both non-overlapping and overlapping momentum portfolios. Research in Australia is limited to the examination of nonoverlapping portfolios. Thus, the question of the robustness of overlapping portfolios suggested in Jegadeesh and Titman, (1993, 2001) and Moskowitz and Grinblatt (1999) is still unclear.

This paper is structured as follows. The next section outlines previous research and explores the equivocal findings in Australian momentum literature. Section 3 and 4 will then discuss the data and methodology respectively. Results are presented in section 5 and section 6 concludes.

\section{Literature review}

Hurn and Pavlov (2003) are among the first to study the momentum effect in Australia. They source their monthly data for the period December 1973 to December 1998 from the Center for Research in Finance (CRIF) at the University of New South Wales. Because the majority of stocks listed on the ASX are small and illiquid stocks, they limit their sample to the top 200 stocks by market capitalization. Despite this restriction, their final dataset still has a considerable number of months when stocks are not traded and hence no return is recorded. ${ }^{1}$ The authors offer three solutions to the problem of missing values. The first approach is also used by CRIF database and ASX to construct market indices. If a stock is not traded in a particular month, the last recorded price is used to calculate returns. All missing period returns were thus

\footnotetext{
${ }^{1}$ Many studies collect data from CRIF, but only Hurn and Pavlov (2003) mention and offer solutions to the bias resulting from missing values in CRIF database. The study does not consider the effect of survivorship bias in the sampling methodology.
} 
set to 0 . The second approach is to replace any missing returns with the sample mean returns for each stock using the monthly total return observations. This method inherently biases returns upward. Their third solution is to perform a regression of a three-factor model. They identify the appropriate factors by conducting a principle component analysis of size-sorted portfolio returns. As such, all listed stocks in the CRIF database are ordered on size and the 200 largest stocks are grouped into 10 portfolios. Hurn and Pavlov report that the first two factors are market and size factors commonly encountered in the literature. Due to the lack of historical book-to-market ratios, they cannot interpret the third factor as the excess return on value stocks or the Fama and French (1993) book-to-market factor. Instead, Hurn and Pavlov capture the additional variation in returns on equal-weighted industry portfolios (the third factor). Consequently, the missing returns are then replaced with the estimated returns from their three-factor regression. This method is dependent on the accuracy of the three factors.

Following the methodology described in Jegadeesh and Titman (1993), Hurn and Pavlov (2003) find that the momentum effect is only present in the short to medium term. In particular, momentum returns vary from $0.6 \%$ to $2.73 \%$ per month for the strategies which rank stocks over 6 months and hold them for 6 or 12 months. $^{2}$ The profit of a winner minus loser portfolio becomes insignificant when the investment period is extended beyond 12 months. In addition, their findings are robust to the choice of the three methods of inferring missing return values. Hurn and Pavlov (2003) do not examine overlapping portfolios or allow for a skip period between the portfolio formation period and the holding period in their study.

Demir et al. (2004) is the most commonly cited study in the Australian momentum literature. They contribute to the existing literature by investigating the momentum effect using

\footnotetext{
${ }^{2}$ By convention $J / S / K$ denotes a $J$ month ranking period, a $K$ months holding period and $\mathrm{S}$ month skip period between $J$ and $K$.
} 
daily data. Their sample consists of stocks that are approved for short selling and all stocks in S\&P/ASX All Ordinaries Index for the period from July 1996 to July 2001. While Hurn and Pavlov (2003) examine the impact of bias caused by missing values in the sample, Demir et al.(2004) raise the survivorship bias issue. They delete stocks that do not survive on the first 2 days of the holding period. ${ }^{3}$ Following the methodology of Jegadeesh and Titman (1993), these authors examined all possible momentum strategies that rank and hold stocks over 30, 60, 90 and 180 days. As with Hurn and Pavlov (2003), they do not examine overlapping portfolios or allow for a skip period between ranking and holding periods. Demir et al. find a very strong momentum effect with the best and the worst strategies earning monthly returns of $5.34 \%$ and $1.38 \%$ per month, respectively. It should be noted that the magnitude of their momentum profits exceeds those commonly found in the Australian and US momentum literature. For the similar strategy implemented on stocks approved for short-selling it yields profits of about $1.76 \%$ per month which are statistically significant at the $99 \%$ level. Finally, Demir et al. also investigate the effect of size on momentum returns by forming size-neutral portfolios with stocks sorted bytheir market capitalization at the end of portfolio formation period. In contrast to Hurn and Pavlov (2003), they find that the momentum effect is strongest in smaller stocks and declines with market capitalization.

Durand et al. (2006a) examine the momentum effect in Australia from January 1980 to December 2001. They use of broader sample of monthly data for all stocks listed on the ASX without mentioningthe survivorship bias issue. Durand et al. produce striking results in that momentum returns are insignificantly different from zero. For some strategies such as 3/0/3,

\footnotetext{
${ }^{3}$ In overseas momentum literature, only Grundy and Martin (2001) mention the survivorship bias. They offer no solutions but delete stocks that ceased-to-trade from their sample. The bias in this method, as with Demir et al. (2004) and Galariotis (2010), is that it implicitly assumes "perfect foresight" of future delistings or acquisitions. Deleting such stocks from the sample may cause a bias toward finding momentum returns and makes the strategy not investible.
} 
$3 / 0 / 12$ and $12 / 0 / 3$, momentum traders actually incur a significant loss ranging from $-2.612 \%$ to $2.113 \%$ per month which are both economically and statistically significant. In order to reconcile the inconsistency, Durand et al. (2006a) replicated Demir et al. (2004) by considering daily (rather than monthly) returns for all stocks from 1990 to 2001. They find pronounced and statistically significant momentum effect. However, when examining the longer sample period from 1980 to 2001, the momentum effect is not evident. Consequently, Durand et al. (2006a) implicitly hypothesize that the difference between their study and Demir et al. (2004) is unrelated to the choice of sampling frequency but due to the different sample periods of the two studies. The authors do not examine their conjecture further.

Brailsford and O'Brien (2008) also use a broad sample of stocks and a longer sample period. They employ CRIF market data of all stocks listed on ASX from 1979 to 2005. Their sample consists of 986 stocks per year which is larger than 675 stocks per year of Durand et al. (2006a). This also implies that their study include a significantly larger proportion of small stocks compared to others. Nevertheless, biases of missing values and delisted stocks are not mentioned in Brailsford and O'Brien (2008). Brailsford and O'Brien (2008) find no evidence of momentum effect when stocks in portfolios are equally-weighted. However, when the authors form value-weighted momentum portfolios, the investing strategies become profitable with a return of $2.69 \%$ per month although the profits are primarily attributable to the loser portfolios (sell side). By categorizing stocks into four size groups, Brailsford and O'Brien (2008) also find significant momentum returns of about $0.72 \%$ to $0.82 \%$ in the groups of top 50 stocks and 51 -to200 stocks, respectively. The momentum effect weakens when they move down the size-groups and disappears for stocks ranked beyond 500. As with all prior Australian studies, Brailsford and O’Brien (2008) do not examine overlapping portfolios. 
Bettman, Maher and Sault (2009) apply the methodology of Barber and Lyon (1997) to match momentum portfolios based on size and book-to-market ratios from 1990 to 2007. They find that momentum strategies yield excess profits of $17.79 \%$ per year. Moreover, the significant returns are also robust to short-selling restrictions, liquidity constraints and bid-ask spreads on momentum profits. Finally, Bettman et al. (2009) document that investors earn average dollar profits of \$14.46 million from executing Jegadeesh and Titman (1993) momentum strategies in the ASX. Bettman et al. (2009) do not discuss the impact of survivorship bias in their study.

The most recent study is Galariotis (2010) which confirms that momentum effect is strong and robust to sampling period and even exists in times of crisis. As with the literature, Galariotis (2010) assumes "perfect foresight" by deleting stocks that do not trade for three consecutive months in his sample. He also does not examine overlapping portfolios. The most notable contribution of Galariotis (2010) is the examination of three-factor model of Fama and French (1993). In general, although he generally finds that the Fama and French three-factor model cannot explain momentum returns, the findings are mixed across various investing strategies. For a 6/0/6 strategy that is commonly examined in the literature, Galariotis (2010) finds that the Fama French three-factor model can fully explain momentum profits. This contrasts with the vast majority of studies in the US (e.g. Fama and French, 1996 and Jegadeesh and Titman, 2001). One possible reason for those inconsistent results is that Galariotis (2010) constructs the Fama and French three factors using book-to-market ratios of firms in the S\&P/ASX200 index from 2000 to 2007. Thus, the sample is small with only 349 firms over the sample period. This suggests a need for a further examination of the Fama French three-factor model by employing all ASX listed stocks for a longer time period. Constructing Fama French three factors using the universe of ASX stocks is also suggested by Halliwell et al. (1999), 
Durand et al. (2006b), O'Brien et al. (2008) and Dempsey (2010) who examine the three factors in other research areas. Finally, it will also provide results which can be compared to those of overseas literature.

In summary, the evidence of momentum effect in the Australian equity market is still equivocal. What is more certain is that the momentum effect is present in the biggest ASX companies by market capitalization. No momentum studies in Australia provide a complete examination of momentum portfolios which can be constructed using both non-overlapping and overlapping strategies. Jegadeesh and Titman $(1993,2001)$ and Moskowitz and Grinblatt (1999) suggest that using overlapping portfolios helps reduce the effects of bid-ask bounce and hence provides more robust results. In practice, it is also more realistic that institutional investors revise their positions monthly. The impact of survivorship bias on the findings of momentum returns is also not explored although several studies notice in footnotes that the bias exists. Finally, the Australian literature also contains little evidence of the power of the Fama and French three factor model in explaining momentum returns, only Galariotis (2010) reports equivocal results.

\section{Data}

\subsection{Accounting data}

The data employed in this study includes market data and accounting data. The constituent list and corresponding annual book values of total equity of all companies listed on the ASX from January 1993 to December 2008 are collected from Aspect Huntley's DataLink Financial database. The sample period starts after publication of Jegadeesh and Titman (1993)An advantage of our study is that we sample in more recent years (from 1993 to 2008) when electronic database such as Aspect Financial can supply reliable quality of accounting data 
(including total assets, total liabilities, and total shareholder equity) of all ASX-listed companies. We follow Fama and French (1993) to calculate total book values of equity and exclude firms with negative book as well as missing observations. On average, our sample comprises 1,552 firms per year and a minimum of 905 firms in 1993 The number of firms increases to 1,826 companies in 2008. In total, there are 251,249 observations over the sample period. Our sample covers approximately $86 \%$ of all firms in CRIF database. ${ }^{4}$

Prior research that tests the three-factor model of Fama and French (1993) on Australian equity returns is used to gauge the degree of coverage of our book-to-market ratios. O'Brien et al. (2008) possesses the largest sample of book-to-market ratios which is hand-collected from 1981 to 2005. Their data contains approximately $98 \%$ of all companies captured in CRIF. Although our sample size is smaller than O'Brien et al. (2008), it is substantially increased over previous studies in Australia that also collect book values such as Halliwell, Heaney and Sawicki (1999), Gaunt (2004), Durack et al. (2004), Durand et al. (2006), Kassimatis (2008) and even the most recent study of Galariotis (2010). These studies cover less than $50 \%$ of all firms listed on ASX. $^{5}$ To the best of our knowledge, the Aspect Financial database supplies the most comprehensive historical accounting data in Australia.

\footnotetext{
${ }^{4}$ Our sample is similar to that of Dempsey (2010) who also collects book values data from Aspect Financial database. In order to maintain the accuracy of our estimates, we only use data from 1993 to 2008 to construct the Fama French three factors since we notice that the quality of book values before was questionable.

${ }^{5}$ Only Galariotis (2010) examines a Fama French three-factor model on momentum returns. Galariotis collects book-to-market data from Datastream International for S\&P/ASX200 stocks from 2000 to 2009, with only 349 firms in his sample. See O'Brien et al. (2008) for a comparison of sample size in Australian studies. O'Brien et al. also argued that preceding studies' book-to-market values are fewer than 50\% of all stocks listed on the ASX.
} 


\subsection{Market data}

Because there is no sole database offering both accounting and market data in Australia, we first collect accounting data of all ASX listed stocks from Aspect Huntley's and then use the list of stocks with accounting data to find the corresponding market values from CRIF. The returns on stocks provided by CRIF are adjusted for changes to the number of shares outstanding, stock splits, stock dividends, spin-offs, stock distributions and rights issues. The CRIF database also contains monthly 13-week Treasury note yields and monthly market returns of all ASX stocks. Book-to-market ratios (book values from Aspect divided by the corresponding market values from CRIF) are then calculated for all ASX-listed companies at the end of the financial year (that is June).

Conrad and Kaul (1993) point out the upward bias to returns caused by including small stocks in the sample. They show that the reversion of returns on long-term contrarian strategies is due to the inclusion of small and low-priced stocks. For this reason, Jegadeesh and Titman (2001) exclude stocks priced below $\$ 5$ in their construction of momentum portfolios. The exclusion of such stocks ensures that the findings are not caused primarily by small and illiquid stocks or the bid-ask bounce. In Australia, Brailsford and O'Brien (2008) and other prior research confirm that the momentum effect can only be found in large and mid-cap stocks. These authors also suggest that momentum returns on mid-cap stocks are mainly attributable to the loser portfolios which contained small and illiquid stocks which may be difficult to short sell. The viability of momentum designs that consider the whole universe of stocks is therefore questionable. Since the majority of stocks listed on the ASX are illiquid, we argue that studies of momentum effect in Australia should not attempt to enlarge the sample to the universe of stocks if the intent is to show evidence for a profitable trading strategy. 
Our objective in this study is to design momentum strategies that are institutionally investable. Consequently, we restrict our sample to the 300 largest stocks listed on the ASX (henceforth ASX300). In the investigation of the momentum effect, we extend the market data to cover from January 1977 to December 2008. ${ }^{6}$ The sample period allows us to examine 16 years pre-Jegadeesh and Titman (1993) and 16 years post-Jegadeesh and Titman (1993). Thus, the results may tell whether publication of the first momentum findings study changed investors' trading behaviour. The final dataset contains 1,740 (live and dead) stocks that ever fall in the top ASX300. The constituent list is updated on a monthly basis. Stocks in the ASX300 are highly liquid that includes large-capitalization and mid-capitalization stocks.

Finally, it is worthwhile to note that, consistent with Jegadeesh and Titman (2001), limiting our study to 300 largest stocks is roughly equivalent to excluding stocks priced below $\$ 1$ which are approximately $67 \%$ of the CRIF universe.

\section{Methodology}

\subsection{Construction of momentum portfolios}

The seminal paper of Jegadeesh and Titman (1993) lays out the methodology to construct momentum portfolios that most momentum studies followed and this study is not an exception. Firstly, at beginning of each month, continuously compounded return on each stock are computed as a criterion to rank stocks over the past $J$ months. This ranking period is also called formation period. To be eligible for ranking, stocks must have a return history of $J$ months and be actively traded from the beginning to the end of formation period. The restriction is necessary since returns on stocks that are not actively traded at both endpoints cannot be computed.

\footnotetext{
${ }^{6}$ Momentum trading strategies will be discussed in the methodology section. For now, it should be noted that the strategies require a six months ranking period. Therefore we collect additional data for one year backward in time, 1976.
} 
Moreover, if the stocks are not traded at the end of formation period they cannot be purchased or sold and hence cannot be included in the relative-strength portfolios. This requirement does not induce any bias because all historical information is known prior to time $t$.

Due to the relatively small number of stocks in the sample (300 stocks per month), we do not follow the US literature to group stocks into deciles. Instead, stocks are classified into quintiles where the top quintile includes the best performing stocks over the ranking period and is referred to as the winner portfolio. Correspondingly, the bottom quintile consists of the worst performing stocks over the same period and is referred to as the loser portfolio. Over the sample period each quintile contains 60 stocks. In the next $K$ months (referred to as holding or investment period), relative-strength or momentum strategies enter a long position in an equally weighted portfolio of winners and a short position in an equallyweighted loser portfolio. Hence, the momentum portfolios are also called zero-cost portfolios. Since the portfolios are equally weighted the holding period return of a momentum portfolio is the average of all individual stock returns within the portfolio.

Jegadeesh (1990) and Lehmann (1990) document return reversals in the short term. In particular, they show that current losers are likely to become future winners and vice versa. Lo and MacKinlay (1990), on the other hand, argue that the existence of short-term reversals in many such studies is due to the bid-ask bounce. For this reason, Jegadeesh and Titman (1993) avoid bid-ask spread, price pressure and lagged reaction effects by introducing a one-month skip period between formation and holding period. This convention has been followed by many subsequent momentum studies. We also use a one-month skip period in this study. Stocks are ranked based on their past $J$ months return spanning from $t-J$ to $t-1$ and the winner and loser portfolios are held from $t+1$ to $t+K+1$. 
To be consistent with the vast majority of momentum literature in the US and to increase the power of tests, we construct overlapping portfolios whereby additional new momentum portfolios are formed every month and held until time $t+K+1$. At each month $t$, the winner (loser) return is the equally weighted return of the $k$ winner (loser) portfolios corresponding to the $t-k+1$ to $t$ months. The strategy entails that momentum portfolio of month $t$ will contain all securities that are in the winners and losers of month $K-1$ to month. Overlapping portfolios are used to increase the power of $t$-tests and allows simple $t$-statistics to be used. In addition, Moskowitz and Grinblatt (1999) argued that the utilization of overlapping portfolios helps reduce the effects of the bid-ask bounce and hence provide a more robust result. In practice, it is also more realistic that institutional investors revise their position monthly.

In choosing specific momentum strategies examined, previous research in Australia has shown that momentum returns are significant for strategies that rank stocks over the past 3 to 6 months and hold them for 3 to 6 months (e.g. Hurn and Pavlov (2003), Demir et al. (2004) and Brailsford and O'Brien (2008)). The significant medium-term momentum effect is also consistently found in the US. As a result, this study only examines the strategies that use either a three-month or six-month ranking period. The returns on these strategies with non-overlapping and overlapping periods as well as an optional one-month skipping period are examined.

Finally, since the weighting of the simutaneously held momentum portfolios changes over time due to the differential rates of return accruing to the different portfolios the momentum portfolios are not equallyweighted throughout the holding period. In order to maintain an equal portfolioweighting, we follow Jegadeesh and Titman (1993) and rebalance the portfolios monthly to an equal weighting. This involves selling a proportion of those portfolios 
with above average performance compared to those with a worse performance during the holding period. The proceeds will then be used to purchase the poorer performing portfolios.

\subsection{Controversy in handling biases}

There are cases where stocks are eligible to be considered in the formation period but cease to trade before the end of investment period. Grundy and Martin (2001) address this issue by deleting those stocks from their sample. They notice that when winners are delisted, it is typically the result of a merger or takeover during the formation period. The news about acquisitions is likely to cause the superior performance of those stocks during the formation period. In contrast, the losers are delisted because of liquidation or other negative performance related reasons. In Australia, Demir et al. (2004) impose similar requirement in the sample construction. Subsequent studies in Australia do not mention this portfolio selection issue. In the present study, we refer to this approach as 'conventional sampling method'. The approach implicitly assumes that investors possessed 'perfect foresight' of future delistings and acquisitions and hence, do not include those stocks in their portfolios at time of portfolio formation. This presumption of foresight causes return biases in previous research. Since the objective of our study is to examine investable momentum returns, we will address this shortcoming. ${ }^{7}$ We adopt a conservative sampling method that is used in several studies (e.g. Henker, Martens and Huynh (2006) and Gaunt and Gray (2003)). ${ }^{8}$ If the stocks do not exist or trade by the time a new portfolio is formed (month $t$ ), they are not included in winner or loser portfolios since we cannot acquire these securities to include them in any portfolio. This does

\footnotetext{
${ }^{7}$ It would be ideal if the data of delistings were available in Australia. This would allow us to obtain returns on stocks after they are delisted or acquired. However, there is no database such as CRSP (Center for Research in Security Prices) in the US that offers the data for the Australian market.

${ }^{8}$ Gaunt and Gray (2003) study the short-term autocorrelation in Australian equities. They use a similar method to eliminate survivorship bias in their sample.
} 
not induce bias since the information is known by the time of portfolio formation. For stocks that exist and trade in month $t$ but cease to exist in the subsequent months of the investment period, we assume that those stocks are liquidated and subsequently worthless. This means that their prices are set to zeros and returns on those stocks will then be $-100 \%$ in the delisting month and zeros in the subsequent months. The momentum returns will be a lower bound of actual portfolio returns because it accounts properly for failed company returns and downward biases returns of portfolios containing acquired or merged companies.

Although the approach is conservative, it is superior to the conventional sampling method because it does not require any foresight. The liquidating amount, if any, may be instead deposited into cash management account that in effect earns relatively insignificant returns for the rest of a holding period. In the present study, we refer to this way of handling the survivorship bias as 'practical approach'. By replicating previous research in the next section, we argue that ignoring such stocks leads to a significant bias towards finding a momentum effect. This bias may get worse in studies that employ a universe of ASX stocks since the large number of small stocks in their samples is more likely to be delisted or acquired.

Besides a delisting bias, the CRIF database also suffers from a bias created bymissing returns when stocks are not traded on the final trading day of a month. ${ }^{9}$ These missing values are recorded as price relatives of -9 and -99 in the database. Although we have limited our study to the biggest 300 stocks on the ASX, the resultant dataset still contains a large number of observations with missing returns. Hurn and Pavlov (2003) suggest three solutions for handling these missing prices as discussed in the literature review. Since they find that different

\footnotetext{
${ }^{9}$ Such stocks record returns in following months. On average, the stocks with missing returns and delisted stocks together affect $7.84 \%$ (about 5stocks per holding period) of the winners and $13.45 \%$ (approximately 8 stocks per holding period) of the losers for the 6/0/6 overlapping portfolios from 1977 to 2008 . The difference in these percentages is expected since winner stocks are larger and hence less likely to be delisted than loser stocks over time.
} 
approaches produce similar results, we adopt their first simple method to impute missing returns with a return of zero for that month. This technique which is also used by the ASX and CRIF databases does not create a bias.

\subsection{Construction of Fama-and-French three factors}

The three-factor model of Fama and French (1993) consists of market risk factor $\left(R_{m}-R_{f}\right)$, the size factor $(S M B)$ and the book-to-market factor $(H M L) . S M B$, small minus big, captures the premium that small stocks earn over large ones while $H M L$, high minus low, captures the premium that value stocks earn over growth stocks. There is no source for reliable Fama-and-French three factors of Australian companies. Hence we follow the original methodology of Fama and French (1993) to construct the common risk factors for the companies in our sample.

We notice that different Australian tests of the Fama and French three-factor model use different grouping methods in constructing the portfolios of size and book-to-market values. Some use quintiles of book-to-market ratios and size to group stocks (e.g. Halliwell, Heaney and Sawicki (1999)), some follow exactly the grouping method of Fama and French (1993) (e.g. Gaunt (2004)) while others classify the stocks into two groups (e.g. Faff (2004)). ${ }^{10}$ Those studies adjust the categorization of stocks because their sample sizes are small. As this study obtains the universe of ASX-listed stocks to construct the factors, the sample is sufficiently large to closely follow Fama and French (1993) in this matter. The exception is that we rank and classify stocks based on book-to-market values in June of each year $t$ (the end of fiscal year in Australia).

\footnotetext{
${ }^{10}$ See O’Brien et al. (2008) for a discussion of different grouping methods.
} 
To construct the size factor, in December of each year t from 1993 to 2008 and rank all ASX-listed stocks covered in the Aspect database by market capitalization. ${ }^{11}$ We then assign all stocks with market capitalization higher than the median of ASX market capitalization into the big portfolio, B, and the rest into a small portfolio, S. Independently, all ASX stocks are also ranked on book to market values at the fiscal year end. We exclude all stocks with negative book values of equity. The stocks are categorized such that the first $30 \%$ of stocks (growth stocks) has the lowest book to market ratios, L; the next $40 \%$ of stocks is assigned to medium portfolio, M, and the remaining $30 \%$ of stocks (value stocks) comprise the high, $\mathrm{H}$, portfolio. In the next step, we construct six intersection portfolios $(\mathrm{S} / \mathrm{L}, \mathrm{S} / \mathrm{M}, \mathrm{S} / \mathrm{H}, \mathrm{B} / \mathrm{L}, \mathrm{B} / \mathrm{M}$, and $\mathrm{B} / \mathrm{H})$. These portfolios are held for twelve months and monthly value-weighted returns on those six portfolios are computed from July of year $t$ to June of year $t+1$. The $S M B$ and $H M L$ factors are then calculated as follows. $^{12}$

$$
\begin{aligned}
S M B & =\frac{1}{3}(\text { Small Value }+ \text { Small Neutral }+ \text { Small Growth }) \\
& -\frac{1}{3}(\text { Big Value }+ \text { Big Neutral }+ \text { Big Growth }) \\
H M L & =\frac{1}{2}(\text { Small Value }+ \text { Big Value })-\frac{1}{2}(\text { Small Growth }+ \text { Big Growth })
\end{aligned}
$$

Having constructed the Fama and French three factors, we next perform the following time-series regressions that subsequently examine the explanatory power of each of the three factors. The first time-series regression is one-factor model, capital asset pricing model (CAPM), which regresses the returns on momentum portfolios against the market risk premium (equation 4). We will then add the size $(S M B)$ factor to the model (equation 5). Finally, a full set of Fama and French three-factor model is estimated on momentum returns (equation 6). The Fama and

\footnotetext{
${ }^{11}$ Refer to footnote 4. We only use momentum returns post-Jegadeesh and Titman (1993) from January 1993 to December 2008 when performing Fama-and-French three-factor regressions.

${ }^{12}$ From Fama and French's website: http://mba.tuck.dartmouth.edu/pages/faculty/ken.french/data_library.html
} 
French model is employed to examine the exposure of momentum returns to the three common factors of stock returns. Because previous research in the US has been rejecting the model, we expect to find similar findings in Australia.

$$
\begin{aligned}
& r_{p t}-r_{f}=\alpha_{p}+\beta_{p}\left(r_{m t}-r_{f}\right)+e_{p t} \\
& r_{p t}-r_{f}=\alpha_{p}+\beta_{p}\left(r_{m t}-r_{f}\right)+s_{p} S M B_{t}+e_{p t} \\
& r_{p t}-r_{f}=\alpha_{p}+\beta_{p}\left(r_{m t}-r_{f}\right)+s_{p} S M B_{t}+h_{p} H M L_{t}+e_{p t}
\end{aligned}
$$

where $r_{f}$ is monthly yield on 13-week Treasury bill; $\left(r_{p t}-r_{f}\right)$ is the monthly momentum excess

return (over the risk-free rate, $\left.r_{f}\right)$ on the market index; $\left(r_{m t}-r_{f}\right)$ is the excess return on the value-weighted market index; $S M B_{t}$ is a portfolio representing the returns of small companies minus big ones; $H M L_{t}$ is a portfolio representing returns of companies with high book-to-market ratios over those with low book-to-market ratios; and $e_{p t}$ represents the error term in each of the regressions.

\subsection{Transaction costs}

The returns produced from the methodology outlined above would be overstated as transaction costs of implementing momentum strategies are not considered. In order to account for transaction costs the constituent list of securities in winners and losers are recorded each month. We then compute the number of stocks dropped from the old portfolios and added to the new portfolios. This allows us to calculate the turnover rates of winner and loser portfolios.

Since the relevant data to calculate transaction costs is investor specific, transaction costs computed in the literature are employed. Specifically, we relied on the round-trip transaction costs calculated in Comerton-Forde, Fernandez, Frino and Oetomo (2005) and Comerton-Forde, Gallagher, Nahhas and Walter (2006) to adjust for our raw momentum returns. Using a unique 
institutional trade dataset supplied by one of the top 10 investment managers in Australia, Comerton-Forde et al. (2005) documented execution costs associated with purchases and sales were $0.34 \%$ and $0.16 \%$, respectively. ${ }^{13}$ Comerton-Forde et al. (2006) used similar methodology as the former study but with a larger sample that focused on 12 actively managed Australian small-cap funds in Australia. They reported higher transaction costs than Comerton-Forde et al. (2005) with round-trip transaction costs of $1.09 \%$ for a trade in a small-cap stock. We chose these two studies as representative cases for several reasons. Firstly, their studies used a more current sample period than the others. Further, each study employed different samples of sizes of institutions. Comerton-Forde et al. (2005) provided typical transaction costs for portfolios consisting of large companies while Comerton-Forde et al. (2006) supplied transaction costs for small company portfolios. Finally, both papers considered explicit costs (brokerage fees) and implicit costs (price impacts of trades).

The cost-adjusted returns for momentum portfolios are calculated by subtracting the total round-trip transaction costs of both winners and losers from the raw momentum returns. For winner and loser portfolios, their corresponding round-trip transaction costs were subtracted from the raw returns.

\section{Results}

Using the bias-free sample, we find no momentum effect on the Australian equity market from 1977 to 2008. Since this is in stark contrast to the literature, we replicate previous research using the 'conventional sampling approach' and find robust and consistent results to other studies. We show that the difference is due to our different sampling method which is more investible. In

\footnotetext{
${ }^{13}$ Comerton-Forde et al. (2005) contains only only one individual investment manager over a one-year period which may not be generalize to the entire market
} 
addition, consistent with the literature, we document that the Fama-and-French three-factor model cannot explain the variation in momentum returns in Australia. Finally, we find that adjusting for transaction costs significantly reduces the returns of momentum portfolios under both, the conventional and practical, sampling methods.

\subsection{Momentum returns under practical sampling method}

Table 1 presents average monthly returns for non-overlapping momentum portfolios over the entire period from January 1977 to December 2008. Overall, we find that momentum investing strategies are not profitable or even making a loss in some holding periods. In all strategies, returns on both winners and loser portfolios are statistically significant and positive. Past losers outperform past winners by about $0.4 \%$ to $1 \%$ per month although the returns varied substantially for different formation and holding periods. For instance, the strategy ranking stocks over the past 6 months and holding the portfolio for 12 months with a one-month skip period $(6 / 1 / 12)$ earns negative return of $-1.03 \%$ per month, while the $6 / 1 / 6$ strategy earns $-0.04 \%$ per month. Portfolios allowing a one-month skip gap between ranking and holding periods produce similar statistically and economically insignificant results.

\section{$<$ Insert Table 1 here $>>>$}

To increase the power of student $t$ tests, we construct overlapping portfolios in which a momentum strategy is followed every month. Results are reported in table 2. Utilizing overlapping momentum portfolios does not change the earlier results. On average, momentum traders cannot earn significantly positive returns although both winner and loser portfolios exhibit a strong momentum effect. Indeed, consistent with existing arguments about the advantages of overlapping portfolios, we find that negative momentum returns are now more 
robust and significant than before. Returns on winner-minus-loser portfolios are even more negative. Past losers again yield significantly positive returns and outperform their winner counterpart by approximately $1 \%$ per month. In other words, the losses are primarily caused by the good performance of the loser portfolio. For instance, strategies ranking stocks over the past 6 months and holding them for 6 months produce a loss of $1.03 \%$ which is statistically significant at the $99 \%$ level. This loss is due to the loser portfolios which make an average return of $1.63 \%$ outperforming the winners by $1.03 \%$ per month. Finally, consistent with studies in the US, we document an increase in momentum returns (a smaller loss) when a one-month skip between ranking and holding periods is added.

We notice that our findings are inconsistent with the research of Hurn and Pavlov (2003), Demir et al. (2004); Marshall and Cahan (2005) and Brailsford and O'Brien (2008). However, we support the findings of Durand et al. (2006) who find no momentum effect from 1980 to 2001 using monthly data. In overseas momentum literature, we also support the findings of Henker, Martens and Huynh (2006) who employ a similar sampling method for US data from 1993 to 2004 and find no evidence for a momentum effect. ${ }^{14}$

\section{$<<$ Insert table 2 here $>>$}

Figure 1 further examines the negative returns of momentum portfolios. The chart shows a time series of 6-month holding period returns (HPR) of overlapping portfolios that are formed by ranking stocks over the past six months and holding them for six months with a one-month gap between formation and investment periods (6/1/6). Returns are highly volatile with negative returns in most months. The figure suggests that momentum returns are more volatile and

\footnotetext{
${ }^{14}$ Henker, Martens and Huynh (2006) do not replicate the 'conventional sampling method'. Rather, they reconcile the inconsistency by examining momentum return in sub-periods. Those authors find that US momentum effect is only present from 1993 to 2000 and becomes insignificant over entire sample period due to the technology crash from 2001 to 2004. Thus, the impact of the perfect-foresight assumption is also not explored in their study.
} 
negative before January 1993. This suggests a further examination of momentum returns pre1993 and post-1993 (before and after Jegadeesh and Titman (1993) was published).

\section{< Insert figure 1 here $>>$}

Table 3 presents the momentum returns in two sub-periods. The first sub-period is from 1977 to 1992 and the second sub-period from 1993 to 2008. Consistent with our initial assessment, the volatility of momentum returns pre-1993 is $4.73 \%$ which is $1.56 \%$ higher than the volatility post-1993. This causes momentum returns of $-1.37 \%$ in the first sub-period to be significant at the $99 \%$ level while the negative returns of $-0.22 \%$ in the second sub-period is not significant.

\section{$<<$ Insert table 3 here $>>$}

\subsection{Momentum returns under conventional sampling method}

In order to reconcile our finding which are inconsistent with the literature and to show the impact of survivorship bias, we replicate the 'conventional methodology' using the same sample as used before for the period from 1977 to 2008. As noted in Grundy and Martin (2001), the 'conventional sampling approach' deletes stocks that have ceased to exist during the investment period. Returns on momentum portfolios after exclusion of those delisted stocks are reported in table 4 .

We findsignificantly positive momentum returns for all strategies with similar magnitude to previous research in Australia. Momentum strategies yield statistically significant returns ranging from $0.5 \%$ to $3 \%$ per month which is due to the good performance of past winners. For 
non-overlapping portfolios reported in panel $\mathrm{A}$, the most significant strategy is 3/0/12 yielding significant return of $1.47 \%$ per month. The least profitable strategies are $6 / 0 / 3$ and $6 / 1 / 3$ with returns of $0.25 \%$ and $0.22 \%$, respectively.

Returns of overlapping portfolios are reported in panel B of table 4. Consistently, our replication produces more robust results using overlapping strategies. Momentum profits are all positive and slightly higher after we allow for a one-month skip period between the portfolio formation and investment periods. The most profitable strategy is $6 / 1 / 3$ with $0.87 \%$ per month which is significant at the $99 \%$ level while the least profitable strategy is $6 / 1 / 12$ with $0.22 \%$ return. The magnitudes are again similar to existing findings.

\section{$<<$ Insert table 4 here $>>$}

In Table 5 we analyze the profits of winner-minus-loser portfolios before and after 1993. Consistent with the findings in the previous section, we find a decrease in volatility of momentum returns from $4.19 \%$ pre-1993 to $3.07 \%$ post-1993. In addition, the momentum effect from 1977 to 1992 is also weak with a return of $0.55 \%$ which is significant at the $90 \%$ level. The weak significance is due to the high volatility in returns during the period. The momentum effect is much stronger in the post-1993 sub-period with a return of $0.91 \%$ which is significant at the 99\% level. This suggests that the positive returns documented in previous research can be attributed to the strong effect in the 1990s.

\section{$<<$ Insert table 5 here $>>$}

To conclude, our replication results show that when the assumption of 'perfect foresight' is in place, momentum trading strategies are as profitable. However, when the the alternate sampling strategy, the results reverse to a loss or even significant loss for some strategies. These findings are not attributed to the differences in sample coverage or the time period under 
examination but to the different methods of handling companies that cease to exist. The foremost conclusion drawn from these results is that the momentum effect is not robust to different sampling methods. Assuming perfect foresight has a certain impact on findings of momentum effect and hence could not be ignored. We will use the 'practical' results reported in tables 2 for the rest of this study. In particular, we will choose the strategy of 6-month/6-month with onemonth skip period to examine in detail. This is also consistent with the literature as 6/1/6 strategy was also examined in most momentum studies. ${ }^{15}$

\subsection{Factor sensitivity analysis}

This section analyzes the sensitivity of momentum returns on the three risk factors of Fama and French (1993) for the period post-Jegadeesh and Titman (1993). Panel A, B and C of Table 6 presents time-series regressions of equations (4), (5) and (6).

Panel A shows that after adjusting for market risk, winner portfolios earn a negative return of $-0.25 \%$ while loser portfolios earn almost zero returns over the period. Both alphas of winners and losers are insignificantly different from zero. Consistent with Brailsford and O'Brien (2008), winner portfolios are slightly more exposed to movements of the market than the losers (An average beta of 0.93 for winners compared to 0.83 for losers). Betas of winners and losers are also statistically significant at the $99 \%$ level. Further, we notice that risk-adjusted returns of the relative-strength portfolios are still negative with $-0.71 \%$ per month which is statistically significant at the $99 \%$ level. Comparing this return with the raw return of $-0.75 \%$ per month

\footnotetext{
${ }^{15}$ In the first robustness check, we construct value-weighted momentum portfolios as in Brailsford and O'Brien (2008). Second, we ranked stocks based on cumulative returns as suggested by Grundy and Martin (2001). Finally, geometric mean returns were employed as an alternative performance evaluation. In summary, our findings are robust to each of these checks. Momentum investors cannot on average profit from the arbitrage strategies once the perfect-foresight in portfolio selection was removed.As a robustness test for the length of perfect foresight, we follow Demir et al. (2004) and Galariotis (2010) to delete stocks that do not survive in the first month of the holding period. We find qualitatively consistent results that momentum returns are significant.
} 
suggests that the adjustment for the market risk premium alone does not change the economic loss to momentum investors. Nevertheless, it is interesting that the market factor can explain returns of winners and losers as their corresponding alphas become statistically insignificant.

Panel B reports the explanatory power of the two-factor model of equation (5). Winners are slightly more sensitive to the market risk factor than losers with betas of 0.91 and 0.81 respectively. However, the losers are more exposed to the size factor with the loading of 0.093 while winners' size loading is 0.083 . The alpha of winners is significantly negative whereas the alpha of losers is now insignificantly negative. This means that the winners still do not outperform the losers under the two-factor model. In addition, the two factors are insignificant in explaining momentum returns. The risk-adjusted momentum profit is still negative and statistically significant. Adding the size factor does not improve the explanatory power of the model as the adjusted $R^{2}$ of the two models are virtually equal. The $F$-statistic of the two-factor model is 1.09 which is not significant even at the $90 \%$ significance level. In other words, we cannot reject the hypothesis that market risk and size are not jointly significant. The size loadings of the winner, loser and momentum portfolios are also similar to Brailsford and O'Brien (2008). However, their model's adjusted $R^{2}(0.3 \%)$ for the two-factor model is lower than ours. The difference in magnitude is probably due to different sample characteristics of their study.

Panel ) presents the sensitivity of winners, losers and momentum portfolios to the three Fama and French common risk factors. Overall, the Fama and French three-factor model improves the explanatory power over the one factor model although it still explains little of the variation in momentum returns; the adjusted $R^{2}$ increases to $5 \%$. This level of adjusted $\mathrm{R}^{2}$ is consistent with O'Brien et al. (2008) and Dempsey (2010). The F-statistic associated with the null of no significant dynamic behavior in momentum portfolios' Fama-French factor loadings is 
78.94 which is significant at the $99 \%$ level. Loser portfolios are more sensitive to both size and book-to-market equity factors than winners. Stocks in the winner potfolio have an average size loading of 0.11 whereas those in the loser portfolio have an average sizeloading of 0.19 . For the HML factor, winners have the loading of 0.07 (t-statistic $=1.58)$ whereas the loading of losers is 0.21 (t-statistic $=3.33)$. These results indicate that loser portfolios are significantly riskier than their winner counterpart. Noticeably, the risk-adjusted returns of winners and losers become statistically insignificant, consistent with Fama and French (1996). The three-factor model still cannot explain all of the momentum returns. Similar to Fama and French (1996), the riskadjusted return is still significantly negative with $-0.94 \%$ which is less than the raw returns of $0.75 \%$ per month. The difference arises because losers are more sensitive to Fama and French factors. Finally, as documented in US studies (e.g. Jegadeesh and Titman (2001) and Grundy and Martin (2001)), momentum portfolios have negative loadings on size and distress factors. They are also most exposed to the book-to-market factor with the loading of -0.14 (significant at $95 \%$ level).

Inconsistent with our findings, Galariotis (2010) reports the Fama French risk-adjusted returns for a $6 / 0 / 6$ strategy to be insignificantly positive. ${ }^{16}$ One possible reason for the difference is that Galariotis use a smaller sample of only 349 firms for a shorter time period, from 2000 to 2007. Moreover, our sampling methodology is different.

\section{< Insert table 6 here $>>$}

\footnotetext{
${ }^{16}$ Galariotis (2010) finds mixed results on the explanatory power of Fama and French three-factor model. The riskadjusted returns are still significantly positive in other strategies such as 9/0/6 and 6/0/9.
} 


\subsection{Transaction costs}

Given that momentum returns reported from our sample are insignificant or even negative, there is little incentive for investors to pursue the strategies. Hence, examining the profitability net of transaction costs may not be as interesting as if the profits of momentum were significant. Nevertheless, as our replication results are comparable to prior findings, it is of interest to test whether momentum returns documented in previous research can overcome transaction costs.

Consistent with the literature, the turnover of positions in the momentum strategy is much less than $100 \%$ per month (especially for overlapping portfolios) because there are common stocks between overlapping ranking periods (e.g. 5 common months for 6/1/6 overlapping portfolios). The majority of stocks that are classified as winners or losers in the current month, $t$, are still included in those portfolios for the next month, $t+1$. For the $6 / 1 / 6$ overlapping strategy examined, the turnover rates of winners and losers are virtually equal from 1993 to 2008. On average, $33.915 \%$ of the stocks in the winner portfolio are sold at the end of the holding period while $33.681 \%$ of the stocks in the loser portfolio have to be bought back at the end of the investment period. These figures are consistent with those in US studies such as Grundy and Martin (2001) who report turnover rates for winners and losers of $39.908 \%$ and $36.233 \%$, respectively.

Comerton-Forde et al. (2005) and Comerton-Forde et al. (2006) find that the round-trip transaction cost for large and small-cap managed funds whose trades had identical turnover rates of $67 \%$ are $0.5 \%$ and $1.09 \%$, respectively. Given that our turnover rates for winners and losers are almost half of theirs, the corresponding trsansaction costs for our winners and losers portfolios are both equal to $0.25 \%$ of the portfolio value if we rely on the cost estimates of 
Comerton-Forde et al. (2005). Using the estimates of Comerton-Forde et al. (2006), the corresponding round-trip transaction costs for winner and loser portfolios are $0.548 \%$ and $0.552 \%$, respectively.

Table 7 reports the average returns on momentum portfolios from 1993 to 2008 after accounting for different transaction costs. Column 2 and 3 present momentum returns adjusted for transaction cost estimates of Comerton-Forde et al. (2005) and Comerton-Forde et al. (2006), respectively. Panel A compares results of raw returns (reported again in the first column) and cost-adjusted returns for 6/1/6 overlapping portfolios constructed using our sample. Returns of Winner and loser portfolios become statistically insignificant after adjustment with either cost estimate. Naturally the cost-adjusted returns on momentum portfolios are even more significantly negative. In panel $\mathrm{B}$, which compares raw returns and cost-adjusted returns of our replication results under the conventional sampling method, we observe that transaction costs are not sufficient to eliminate returns on winner portfolios. Under the transaction cost estimate of Comerton-Forde et al. (2006) loser returns become negative with $0.15 \%$ per month. For the relative-strength portfolios, adjusting for transaction costs eliminates the profits and returns become negative if the round-trip transaction costs is $1.09 \%$. We suspect that net momentum profits reported in prior studies would be insignificantly different from zero once transaction costs are considered.

\section{$<<$ Insert table 7 here $>>$}

\section{Conclusion}

We find no evidence for a consistent momentum effect in the Australian equity market since the late 1970s. When we assume perfect-foresight in the sampling methodology we are 
able to replicate results of prior studies in the Australian equity market that conflict with our results. The only difference between our methodology and these other studies is that we do not assume to be able to know in advance which stocks will cease to exist over the investment period Rather, we adopt a conservative approach of Henker et al. (2006) which assumes that those stocks were liquidated and hence had zero prices. We refer to this approach as 'practical sampling method' because it did not need any perfect foresight of future delisting or acquisitions. We argue that previous research may underestimate the severity of their implicit assumption which leads to bias towards finding a momentum effect. Momentum returns are not robust to different sampling approaches. Consequently, future research needs to focus on the consequences of the sampling technique.momentum returns may simply be the product of a lookahead bias during the sampling process. This provides support for the weak form of the efficient market hypothesis.

Our study is the first to use all three Fama-French factors. We are able to collect book values for $86 \%$ of all companies listed on the ASX to make the calculation of book-to-market equity ratios possible. We find that the Fama and French model can only explain $4.7 \%$ of the variation of momentum returns in Australia. The model however is able to explain the returns on winners and losers portfolios. Finally, we showed that the momentum effect is also not robust to transaction costs. Given that our replicated momentum profits are of similar magnitude to previous research, we argue that momentum returns documented in existing studies may not exceed transaction costs. The findings are also additional supports to transaction cost explanations as well as the efficient market hypothesis. A limitation of our results is that we rely on existing estimates of institutional transaction costs in the Australian literature. They are 
average costs which do not take into account the composition of specific momentum portfolios. Consequently, the cost-adjusted profits might be underestimated. 


\section{Appendices}

Figure 1: Time series of momentum returns

The figure shows time series of 6-month holding period returns on overlapping momentum portfolio constructed using 'practical sampling approach'. The overlapping momentum portfolio is formed each month by ranking stocks over the past 6 months and holding for 6 months with one-month skip period (i.e. 6/1/6) for the period from January 1977 to December 2008. Returns on winner-minus-loser portfolios are raw returns (i.e. they are not adjusted for risk factors or transaction costs).

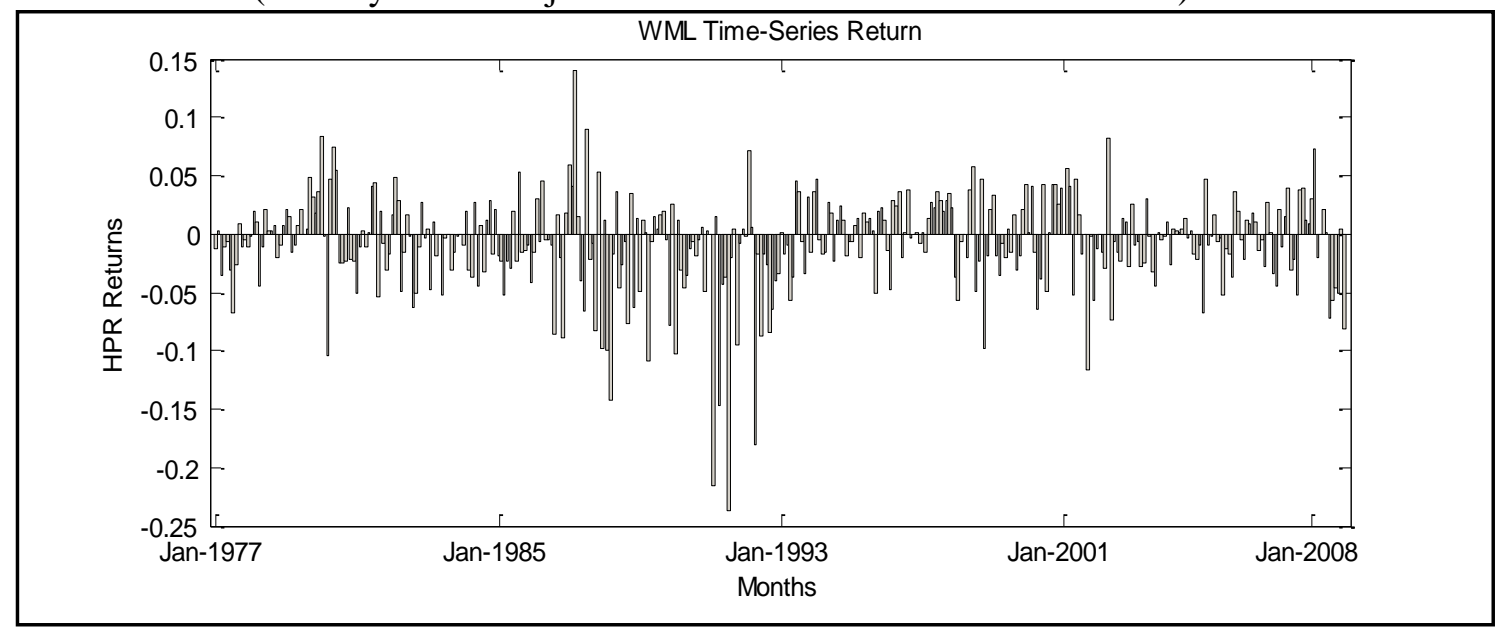


Table 1: Returns on non-overlapping momentum portfolios over entire sample period from January 1977 to December 2008.

The table reports returns on non-overlapping portfolios constructed using 'practical approach' that relaxes the assumption of 'perfect foresight'. The momentum portfolios are formed by ranking ASX300 stocks by continuously compounded returns at the end of each $J$-month formation period and grouping them into quintiles. The first quintile (winners) is the equally-weighted portfolio of best performing stocks while the bottom quintile is the equally-weighted portfolio of worst performing stocks (losers) over the past $J$ months. In the next $K$ months, momentum strategy would buy winners and sell the losers. The winnerminus-loser (WML) portfolios are either formed immediately after ranking period or one month after ranking period. Average monthly returns on each strategy are reported along with the t-statistics in parentheses where *,** and $* * *$ denote significance at $90 \%, 95 \%$ and $99 \%$ level.

\begin{tabular}{|c|c|c|c|c|c|c|c|}
\hline & & & No Skip Perio & & On & -month skip $\mathrm{p}$ & iod \\
\hline & & & lding Period & & & lding Period & \\
\hline$J$ & & 3 & 6 & 12 & 3 & 6 & 12 \\
\hline 3 & Winner & $\begin{array}{l}0.006 \\
(3.102)^{* * *}\end{array}$ & $\begin{array}{c}0.008 \\
(3.580) * * *\end{array}$ & $\begin{array}{l}0.008 \\
(2.732)^{* * *}\end{array}$ & $\begin{array}{l}0.009 \\
(2.911)^{* * *}\end{array}$ & $\begin{array}{l}0.008 \\
(3.636)^{* * *}\end{array}$ & $\begin{array}{l}0.007 \\
(2.635)^{* * *}\end{array}$ \\
\hline & Loser & $\begin{array}{l}0.014 \\
(5.128)^{* * *}\end{array}$ & $\begin{array}{l}0.018 \\
(5.816) * * *\end{array}$ & $\begin{array}{l}0.016 \\
(5.159) * * *\end{array}$ & $\begin{array}{l}0.018 \\
(4.881)^{* * * *}\end{array}$ & $\begin{array}{l}0.011 \\
(4.481)^{* * *}\end{array}$ & $\begin{array}{l}0.016 \\
(4.262)^{* * *}\end{array}$ \\
\hline & WML & $\begin{array}{l}-0.008 \\
(-2.898) * * *\end{array}$ & $\begin{array}{l}-0.010 \\
(-2.998)^{* * *}\end{array}$ & $\begin{array}{c}-0.008 \\
(-2.342)^{* *}\end{array}$ & $\begin{array}{l}-0.009 \\
(-2.657)^{* * *}\end{array}$ & $\begin{array}{c}-0.003 \\
(-1.412) \\
\end{array}$ & $\begin{array}{l}-0.009 \\
(-2.399)^{* *}\end{array}$ \\
\hline 6 & Winner & $\begin{array}{c}0.005 \\
(2.464)^{* *}\end{array}$ & $\begin{array}{c}0.005 \\
(2.198) * *\end{array}$ & $\begin{array}{c}0.006 \\
(2.456) * * *\end{array}$ & $\begin{array}{c}0.002 \\
(0.902)\end{array}$ & $\begin{array}{c}0.006 \\
(2.546) * * *\end{array}$ & $\begin{array}{l}0.006 \\
(2.393)^{* *}\end{array}$ \\
\hline & Loser & $\begin{array}{l}0.014 \\
(4.807)^{* * * *}\end{array}$ & $\begin{array}{l}0.016 \\
(5.011) * * *\end{array}$ & $\begin{array}{l}0.015 \\
(4.888) * * *\end{array}$ & $\begin{array}{c}0.002 \\
(0.830)\end{array}$ & $\begin{array}{l}0.010 \\
3.794 * * *\end{array}$ & $\begin{array}{l}0.016 \\
(5.105)^{* * *}\end{array}$ \\
\hline & WML & $\begin{array}{l}-0.009 \\
(-3.212)^{* * *}\end{array}$ & $\begin{array}{l}-0.011 \\
(-3.664) * * *\end{array}$ & $\begin{array}{l}-0.008 \\
(-2.924)^{* * *}\end{array}$ & $\begin{array}{c}0.0002 \\
(0.092)\end{array}$ & $\begin{array}{c}-0.004 \\
(-1.636)\end{array}$ & $\begin{array}{l}-0.010 \\
(-3.554)^{* * *}\end{array}$ \\
\hline
\end{tabular}


Table 2: Returns on overlapping momentum portfolios over the entire period $1977-2008$

The table reports returns on overlapping portfolios constructed using 'practical sampling approach' that relaxes the assumption of 'perfect foresight'. The strategy is followed every month. Momentum portfolios are formed by ranking ASX300 stocks by continuously compounded returns at the end of each $J$-month formation period and grouping them into quintiles. The first quintile (winners) is the equally-weighted portfolio of best performing stocks while the bottom quintile is the equally-weighted portfolio of worst performing stocks (losers) over the past $J$ months. In the next $K$ months, momentum strategy would buy winners and sell the losers. The winner-minus-loser (WML) portfolios are either formed immediately after ranking period or one month after ranking period. Average monthly returns on each strategy are reported along with the t-statistics in parentheses where $* * *$ and $* * *$ denote significance at $90 \%, 95 \%$ and $99 \%$ level.

\begin{tabular}{|c|c|c|c|c|c|c|c|}
\hline \multirow[b]{3}{*}{$J$} & & \multicolumn{3}{|c|}{ No skip period } & \multicolumn{3}{|c|}{ One-month skip period } \\
\hline & & \multicolumn{3}{|c|}{ Holding Period $(K)$} & \multicolumn{3}{|c|}{ Holding Period $(K)$} \\
\hline & & 3 & 6 & 12 & 3 & 6 & 12 \\
\hline 3 & Winner & $\begin{array}{l}0.006 \\
(3.210)^{* * *}\end{array}$ & $\begin{array}{l}0.008 \\
(3.578) * * *\end{array}$ & $\begin{array}{l}0.009 \\
(4.092) * * *\end{array}$ & $\begin{array}{l}0.006 \\
(3.339)^{* * *}\end{array}$ & $\begin{array}{l}0.008 \\
(3.885)^{* * *}\end{array}$ & $\begin{array}{l}0.009 \\
(4.025)^{* * *}\end{array}$ \\
\hline & Loser & $\begin{array}{l}0.014 \\
(6.255)^{* * *}\end{array}$ & $\begin{array}{l}0.016 \\
(6.439) * * *\end{array}$ & $\begin{array}{l}0.0172 \\
(6.895)^{* * *}\end{array}$ & $\begin{array}{l}0.010 \\
(4.715) * * *\end{array}$ & $\begin{array}{l}0.014 \\
(5.817)^{* * *}\end{array}$ & $\begin{array}{l}0.016 \\
(6.443)^{* * *}\end{array}$ \\
\hline & WML & $\begin{array}{l}-0.008 \\
(-3.978) * * *\end{array}$ & $\begin{array}{l}-0.009 \\
(-4.551)^{* * *}\end{array}$ & $\begin{array}{l}-0.008 \\
(-5.137)^{* * *}\end{array}$ & $\begin{array}{l}-0.004 \\
(-2.251)^{* *}\end{array}$ & $\begin{array}{l}-0.006 \\
(-3.519) * * *\end{array}$ & $\begin{array}{l}-0.007 \\
(-4.459)^{* * *}\end{array}$ \\
\hline 6 & Winner & $\begin{array}{c}0.004 \\
(2.285) * *\end{array}$ & $\begin{array}{l}0.006 \\
(2.774) * * *\end{array}$ & $\begin{array}{l}0.006 \\
(2.805) * * *\end{array}$ & $\begin{array}{l}0.005 \\
(2.518)^{* *}\end{array}$ & $\begin{array}{l}0.007 \\
(3.107) * * *\end{array}$ & $\begin{array}{l}0.006 \\
(2.720) * * *\end{array}$ \\
\hline & Loser & $\begin{array}{l}0.014 \\
(5.787)^{* * *}\end{array}$ & $\begin{array}{l}0.016 \\
(6.042)^{* * *}\end{array}$ & $\begin{array}{l}0.0177 \\
(6.736)^{* * *}\end{array}$ & $\begin{array}{l}0.011 \\
(4.767)^{* * *}\end{array}$ & $\begin{array}{l}0.014 \\
(5.665)^{* * *}\end{array}$ & $\begin{array}{l}0.016 \\
(6.360)^{* * *}\end{array}$ \\
\hline & WML & $\begin{array}{l}-0.010 \\
(-4.527) * * *\end{array}$ & $\begin{array}{l}-0.010 \\
(-4.616) * * *\end{array}$ & $\begin{array}{l}-0.011 \\
(-5.565)^{* * *}\end{array}$ & $\begin{array}{l}-0.006 \\
(-3.128) * * *\end{array}$ & $\begin{array}{l}-0.008 \\
(-3.845)^{* * *}\end{array}$ & $\begin{array}{l}-0.010 \\
(-5.162)^{* * *}\end{array}$ \\
\hline
\end{tabular}


Table 3: Momentum effect before and after Jegadeesh and Titman (1993)

The table reports average returns on 6/1/6 overlapping portfolios constructed using 'practical sampling approach' that relaxes the assumption of perfect foresight. The strategy is followed every month. Momentum portfolios are formed by ranking ASX300 stocks by continuously compounded returns at the end of each 6-month formation period and grouping them into quintiles. The first quintile (winners) is the equally-weighted portfolio of best performing stocks while the bottom quintile is the equally-weighted portfolio of worst performing stocks (losers) over the past 6 months. In the next 6 months, momentum strategy would buy winners and sell the losers. There is one month 'gap' between formation and investment periods. Average monthly returns on each strategy are reported along with the $t$-statistics in parentheses where $*, * *$ and $* * *$ denote significance at $90 \%, 95 \%$ and $99 \%$ level. WML is average return on winner-minus-loser portfolios.

\begin{tabular}{l|cc}
\hline Portfolios & $1977-1992$ & $1993-2008$ \\
\hline Winner & 0.009 & 0.006 \\
& $(2.542)^{* *}$ & $(1.807)^{*}$ \\
Loser & 0.023 & 0.008 \\
& $(5.352)^{* * *}$ & $(2.396)^{* *}$ \\
WML & -0.014 & -0.002 \\
& $(-4.030)^{* * *}$ & $(-0.957)$ \\
\hline
\end{tabular}


Table 4: Replication results over the entire sample period 1977 to 2008

The table reports average monthly returns on both overlapping and non-overlapping momentum portfolios. We replicate the 'conventional approach' that ignores ceased-to-exist stocks during investment period. The only difference between this table and tables 5.1, 5.2 is in the sampling process. Panel A reports average returns on non-overlapping portfolios while panel B presents those for overlapping portfolios. $t$-statistics are reported in parentheses where $*, * *$ and $* * *$ denote significance at $90 \%, 95 \%$ and $99 \%$ level. WML is average return on the winner-minus-loser portfolio.

Panel A: Non-overlapping portfolios

\begin{tabular}{|c|c|c|c|c|c|c|c|}
\hline \multirow[b]{3}{*}{$J$} & & \multicolumn{3}{|c|}{ No Skip Period } & \multicolumn{3}{|c|}{ One-month skip period } \\
\hline & & \multicolumn{3}{|c|}{ Holding Period (K) } & \multicolumn{3}{|c|}{ Holding Period (K) } \\
\hline & & 3 & 6 & 12 & 3 & 6 & 12 \\
\hline 3 & Winner & $\begin{array}{l}0.007 \\
(3.474) * * *\end{array}$ & $\begin{array}{l}0.0191 \\
5.4444 * * *\end{array}$ & $\begin{array}{l}0.040 \\
(7.415)^{* * * *}\end{array}$ & $\begin{array}{c}0.002 \\
(1.084)\end{array}$ & $\begin{array}{l}0.009 \\
(2.652) * * *\end{array}$ & $\begin{array}{l}0.0248 \\
(5.354)^{* * *}\end{array}$ \\
\hline & Loser & $\begin{array}{c}0.003 \\
(1.317)\end{array}$ & $\begin{array}{l}0.0079 \\
2.397 * *\end{array}$ & $\begin{array}{l}0.025 \\
(4.891)^{* * * *}\end{array}$ & $\begin{array}{c}-0.001 \\
(-0.612)\end{array}$ & $\begin{array}{l}0.003 \\
(1.080)\end{array}$ & $\begin{array}{l}0.022 \\
(4.789) * * *\end{array}$ \\
\hline & WML & $\begin{array}{l}0.004 \\
(2.537) * *\end{array}$ & $\begin{array}{l}0.0112 \\
(4.107)^{* * *}\end{array}$ & $\begin{array}{l}0.015 \\
(3.697)^{* * * *}\end{array}$ & $\begin{array}{l}0.004 \\
(2.525)^{* *}\end{array}$ & $\begin{array}{l}0.006 \\
(2.530)^{* *}\end{array}$ & $\begin{array}{c}0.003 \\
(0.977)\end{array}$ \\
\hline 6 & Winner & $\begin{array}{l}0.004 \\
(2.759) * * *\end{array}$ & $\begin{array}{l}0.007 \\
(2.926)^{* * *}\end{array}$ & $\begin{array}{l}0.015 \\
(3.892)^{* * * *}\end{array}$ & $\begin{array}{l}0.0054 \\
(3.975)^{* * *}\end{array}$ & $\begin{array}{l}0.008 \\
(2.961) * * *\end{array}$ & $\begin{array}{l}0.014 \\
(3.712)^{* * *}\end{array}$ \\
\hline & Loser & $\begin{array}{c}0.001 \\
(0.839)\end{array}$ & $\begin{array}{c}0.002 \\
(0.629)\end{array}$ & $\begin{array}{l}0.011 \\
(2.792)^{* * *}\end{array}$ & $\begin{array}{l}0.003 \\
(2.307)^{* *}\end{array}$ & $\begin{array}{c}0.004 \\
(1.638)\end{array}$ & $\begin{array}{l}0.012 \\
(3.579)^{* * *}\end{array}$ \\
\hline & WML & $\begin{array}{l}0.003 \\
(2.009) * *\end{array}$ & $\begin{array}{l}0.006 \\
(2.943)^{* * *}\end{array}$ & $\begin{array}{c}0.004 \\
(1.382)\end{array}$ & $\begin{array}{c}0.0022 \\
(1.695)^{*}\end{array}$ & $\begin{array}{l}0.004 \\
(2.056)^{* *}\end{array}$ & $\begin{array}{c}0.002 \\
(0.673)\end{array}$ \\
\hline
\end{tabular}

Panel B: Overlapping portfolios

\begin{tabular}{|c|c|c|c|c|c|c|c|}
\hline \multirow[b]{3}{*}{$J$} & & \multicolumn{3}{|c|}{ No Skip Period } & \multicolumn{3}{|c|}{ One-month skip period } \\
\hline & & \multicolumn{3}{|c|}{ Holding Period $(\mathrm{K})$} & \multicolumn{3}{|c|}{ Holding Period $(\mathrm{K})$} \\
\hline & & 3 & 6 & 12 & 3 & 6 & 12 \\
\hline 3 & Winner & $\begin{array}{l}0.010 \\
(3.714)^{* * *}\end{array}$ & $\begin{array}{l}0.011 \\
(4.099)^{* * *}\end{array}$ & $\begin{array}{l}0.010 \\
(3.914)^{* * *}\end{array}$ & $\begin{array}{l}0.011 \\
(4.082)^{* * *}\end{array}$ & $\begin{array}{l}0.011 \\
(4.125)^{* * *}\end{array}$ & $\begin{array}{l}0.010 \\
(3.757)^{* * * *}\end{array}$ \\
\hline & Loser & $\begin{array}{l}0.007 \\
(2.332)^{* *}\end{array}$ & $\begin{array}{l}0.006 \\
(2.336)^{* *}\end{array}$ & $\begin{array}{l}0.007 \\
(2.820)^{* * *}\end{array}$ & $\begin{array}{c}0.003 \\
(1.285)\end{array}$ & $\begin{array}{l}0.006 \\
(2.173)^{* *}\end{array}$ & $\begin{array}{l}0.007 \\
(2.792) * * *\end{array}$ \\
\hline & WML & $\begin{array}{l}0.004 \\
(1.970) * *\end{array}$ & $\begin{array}{l}0.005 \\
(3.336)^{* * *}\end{array}$ & $\begin{array}{l}0.003 \\
(2.862)^{* * *}\end{array}$ & $\begin{array}{l}0.008 \\
(4.521)^{* * *}\end{array}$ & $\begin{array}{l}0.005 \\
(3.988)^{* * *}\end{array}$ & $\begin{array}{l}0.003 \\
(2.687)^{* * * *}\end{array}$ \\
\hline 6 & Winner & $\begin{array}{l}0.011 \\
(3.989)^{* * *}\end{array}$ & $\begin{array}{l}0.012 \\
(4.221)^{* * *}\end{array}$ & $\begin{array}{l}0.010 \\
(3.488)^{* * *}\end{array}$ & $\begin{array}{l}0.011 \\
(4.145)^{* * *}\end{array}$ & $\begin{array}{c}0.0113 \\
(4.106)^{* * * *}\end{array}$ & $\begin{array}{l}0.009 \\
(3.292)^{* * *}\end{array}$ \\
\hline & Loser & $\begin{array}{c}0.003 \\
(1.127)\end{array}$ & $\begin{array}{l}0.005 \\
(1.888)^{* * *}\end{array}$ & $\begin{array}{l}0.007 \\
(2.446)^{* *}\end{array}$ & $\begin{array}{c}0.003 \\
(0.952)\end{array}$ & $\begin{array}{c}0.005 \\
(1.688)\end{array}$ & $\begin{array}{l}0.007 \\
(2.593) * * *\end{array}$ \\
\hline & WML & $\begin{array}{l}0.008 \\
(3.885)^{* * *}\end{array}$ & $\begin{array}{l}0.006 \\
(3.580)^{* * *}\end{array}$ & $\begin{array}{l}0.003 \\
(2.082)^{* *}\end{array}$ & $\begin{array}{l}0.009 \\
(4.416)^{* * *}\end{array}$ & $\begin{array}{l}0.007 \\
(3.875)^{* * * *}\end{array}$ & $\begin{array}{c}0.0022 \\
(1.516)\end{array}$ \\
\hline
\end{tabular}


Table 5: Momentum effect before and after Jegadeesh and Titman (1993)

The table reports average returns on 6/1/6 overlapping portfolios constructed using "conventional sampling approach" that has the assumption of perfect foresight in place. The strategy is followed every month. Momentum portfolios are formed by ranking ASX300 stocks by continuously compounded returns at the end of each 6-month formation period and grouping them into quintiles. The first quintile (winners) is the equally-weighted portfolio of best performing stocks while the bottom quintile is the equally-weighted portfolio of worst performing stocks (losers) over the past 6 months. In the next 6 months, momentum strategy would buy winners and sell the losers. There is one month 'gap' between formation and investment periods. Average monthly returns on each strategy are reported along with the $t$-statistics in parentheses where $*, * *$ and $* * *$ denote significance at 90\%, 95\% and 99\% level. WML is average return on winner-minus-loser portfolios.

\begin{tabular}{l|cc}
\hline Portfolios & $1977-1992$ & $1993-2008$ \\
\hline Winner & 0.012 & 0.013 \\
& $(2.440)^{* *}$ & $(3.469)^{* * *}$ \\
Loser & 0.006 & 0.004 \\
& $(1.321)$ & $(1.051)$ \\
WML & 0.006 & 0.009 \\
& $(1.758)^{*}$ & $(4.094)^{* * *}$ \\
\hline
\end{tabular}


Table 6: Sensitivity of momentum returns on the risk factors

Returns on 6/1/6 overlapping portfolios (constructed 'under practical approach') from January 1993 to December 2008 are regressed against the three factors of excess return on market, small minus big (SMB) and high minus low (HML) constructed based on Fama and French (1993). SMB is factor mimicking risk in returns related to size. HML is mimicking risk in returns related to book-to-market equity. Normal time-series regressions with standard errors adjusted for heteroskedasticity are run. $t$-statistics are reported in parentheses in which $*, * *, * * *$ denoted the significant levels of $90 \%, 95 \%$ and $99 \%$, respectively. Panel A estimates one-factor model (equation 4). Panel B reports the estimates of model 5 and results on full set of Fama and French three-factor model (equation 6) are presented in panel C.

Panel A: CAPM

\begin{tabular}{llcc}
\hline & $\alpha$ & $\beta$ & Adjusted $R^{2}$ \\
\hline Winners & -0.0025 & 0.9280 & 0.6179 \\
& $(-1.28)$ & $(13.47)^{* * *}$ & \\
Losers & 0.00008 & 0.8325 & 0.4451 \\
& $(0.03)$ & $(11.44)^{* * *}$ & \\
WML & -0.0071 & 0.0975 & 0.0120 \\
& $(-3.06)^{* * *}$ & $(1.43)$ & \\
\hline
\end{tabular}

Panel B: time-series regression of two-factor model

\begin{tabular}{|c|c|c|c|c|}
\hline & $\alpha$ & $\beta$ & $S$ & Adjusted $R^{2}$ \\
\hline Winners & $\begin{array}{c}-0.0040 \\
(-2.12)^{* *}\end{array}$ & $\begin{array}{c}0.9106 \\
(13.33)^{* * *}\end{array}$ & $\begin{array}{c}0.0828 \\
(3.00)^{* * *}\end{array}$ & 0.6312 \\
\hline Losers & $\begin{array}{l}-0.0017 \\
(-0.67)\end{array}$ & $\begin{array}{c}0.8130 \\
(11.25)^{* * *}\end{array}$ & $\begin{array}{c}0.0925 \\
(2.42)^{* *}\end{array}$ & 0.4600 \\
\hline WML & $\begin{array}{c}-0.0069 \\
(-2.71)^{* * *}\end{array}$ & $\begin{array}{l}0.0994 \\
(1.46)\end{array}$ & $\begin{array}{l}-0.0093 \\
(-0.22)\end{array}$ & 0.0123 \\
\hline
\end{tabular}

Panel C: time-series regression of Fama and French three-factor model

\begin{tabular}{llclll}
\hline & \multicolumn{2}{c}{$\alpha$} & \multicolumn{1}{c}{$\beta$} & \multicolumn{1}{c}{$h$} & Adjusted $R^{2}$ \\
\hline Winners & -0.0028 & 0.9171 & 0.1142 & 0.0687 & 0.6358 \\
& $(-1.53)$ & $(13.75)^{* * *}$ & $(3.26)^{* * *}$ & $(1.58)$ & \\
Losers & 0.0020 & 0.8333 & 0.1895 & 0.2115 & 0.4992 \\
& $(0.87)$ & $(11.78)^{* * *}$ & $(3.60)^{* * *}$ & $(3.33)^{* * *}$ & \\
WML & -0.0094 & 0.0858 & -0.0742 & -0.1414 & 0.0469 \\
& $(-3.68)^{* * *}$ & $(1.150)$ & $(-1.40)$ & $(-2.23)^{* *}$ & \\
\hline
\end{tabular}


Table 7: Momentum returns adjusted for alternative estimates of transaction costs for the period 1993 to 2008

Panel A compares momentum returns before and after adjusted for different transaction costs for the period from 1993 to 2008. The strategy examined is overlapping 6/1/6. Practical sampling method was used such that no look-ahead bias is imposed in the sample. Panel B reports similar things except that portfolios are constructed with the assumption of "perfect foresight" for the period 1993 to 2008. The first column reports again the raw momentum profits. The second column reports momentum returns adjusted for estimate of round-trip transaction costs of $0.25 \%$ for both winners and losers. The costs are calculated based on the proportion of our turnover rates and that documented in Comerton-Forde et al. (2005). Similarly, the third column reports cost-adjusted momentum returns in which round-trip transaction costs are $0.548 \%$ and $0.552 \%$ for winners and losers, respectively. The costs are computed based on the proportion of our turnover rates and that documented in Comerton-Forde et al. (2006). Cost-adjusted returns on momentum portfolios are calculated by subtracting the total costs of winners and losers from the raw momentum profits. For cost-adjusted returns on winners and losers, the corresponding round-trip transaction costs are subtracted from raw returns.

\begin{tabular}{lccc}
\cline { 2 - 4 } Panel A & \multicolumn{2}{c}{ Cost-Adjusted returns } \\
\cline { 2 - 4 } & Raw Returns & Comerton-Forde et al. $(2005)$ & Comerton-Forde et al. $(2006)$ \\
\hline Winners & 0.0055 & 0.0029 & -0.00005 \\
& $(1.8068)^{*}$ & $(0.9709)$ & $(-0.0161)$ \\
Losers & 0.0077 & 0.0051 & 0.0022 \\
& $(2.3962)^{* *}$ & $(1.6102)$ & $(0.6821)$ \\
WML & -0.0022 & -0.0072 & -0.0132 \\
& $(-0.9568)$ & $(-3.1611)^{* * *}$ & $(-5.7641)^{* * *}$ \\
\hline
\end{tabular}

\begin{tabular}{lccc} 
& & \multicolumn{2}{c}{ Cost-Adjusted Returns } \\
\cline { 3 - 4 } Panel B & Raw Returns & Comerton-Forde et al. (2005) & Comerton-Forde et al. $(2006)$ \\
\hline Winners & 0.0131 & 0.0106 & 0.0076 \\
& $(3.4687)^{* * *}$ & $(2.7980)^{* * *}$ & $(2.0060)^{* *}$ \\
Losers & 0.0040 & 0.0015 & -0.0015 \\
& $(1.0507)$ & $(0.3929)$ & $(-0.3837)$ \\
WML & 0.0091 & 0.0040 & -0.0019 \\
& $(4.0948)^{* * *}$ & $(1.8191)$ & $(-0.8681)$ \\
\hline
\end{tabular}




\section{References}

Aitken, Michael, and Alex Frino, 1996, Execution costs associated with institutional trades on the australian stock exchange, Pacific-Basin Finance Journal 4, 45-58.

Barber, Brad M., and John D. Lyon, 1997, Detecting long-run abnormal stock returns: The empirical power and specification of test statistics, Journal of Financial Economics 43, 341-372.

Berkowitz, Stephen A., Dennis E. Logue, and Eugene A. Noser, Jr., 1988, The total cost of transactions on the NYSE, The Journal of Finance 43, 97-112.

Bettman, J. L., T. R. B. Maher, and S. J. Sault, 2009, Momentum profits in the Australian equity market: a matched firm approach, Pacific-Basin Finance Journal 17, 565-579.

Brailsford, Tim, and Michael A. O'Brien, 2008, Disentangling size from momentum in Australian stock returns, Australian Journal of Management 32, 463-484.

Chui, Andy Chun Wai, Kuo-Chiang Wei, and Sheridan Titman, 2000, Momentum, legal systems and ownership structure: An analysis of asian stock markets (SSRN).

Chui, A. C. W., S. Titman, and K. C. J. Wei, 2010, Individualism and momentum around the world, Journal of Finance 65, 361-392.

Comerton-Forde, Carole, Christian Fernandez, Alex Frino, and Teddy Oetomo, 2005, How broker ability affects institutional trading costs, Accounting \& Finance 45, 351-374.

Comerton-Forde, Carole, David R. Gallagher, Jumana Nahhas, and Terry S. Walter, 2006, Transaction costs and institutional trading in small-cap equity funds, SSRN eLibrary.

Conrad, Jennifer, and Gautam Kaul, 1993, Long-term market overreaction or biases in computed returns?, The Journal of Finance 48, 39-63.

Conrad, J, and G Kaul, 1998, An anatomy of trading strategies, Rev. Financ. Stud. 11, 489-519.

Daniel, Kent, Mark Grinblatt, Sheridan Titman, and Russ Wermers, 1997, Measuring mutual fund performance with characteristic-based benchmarks, The Journal of Finance 52, 1035-1058.

Demir, I., J. Muthuswamy, and T. Walter, 2004, Momentum returns in australian equities: The influences of size, risk, liquidity and return computation, Pacific Basin Finance Journal 12, 143-158. 
Dempsey, Michael, 2010, The book-to-market equity ratio as a proxy for risk: evidence from Australian markets, Australian Journal of Management 25.

Durack, Nick, Robert B. Durand, and Ross A. Maller, 2004, A best choice among asset pricing models? The conditional capital asset pricing model in australia, Accounting \& Finance 139-162.

Durand, Robert B., Manapon Limkriangkrai, and Gary Smith, 2006, In america's thrall: The effects of the US market and US security characteristics on Australian stock returns, Accounting \& Finance 577-604.

Durand, Robert B., Manapon Limkriangkrai, and Gary Smith, 2006, Momentum in Australia: a note, Australian Journal of Management 31, 355-64.

Faff, Robert, 2004, A simple test of fama and french model using daily data: Australian evidence, Applied Financial Economics 14, 83-92.

Fama, Eugene F., and Kenneth R. French, 1993, Common risk factors in the returns on stocks and bonds, Journal of Financial Economics.

Fama, Eugene F., and Kenneth R. French, 1996, Multifactor explanations of asset pricing anomalies, The Journal of Finance 51, 55-84.

Foster, F. Douglas, David R. Gallagher, and Adrian Looi, 2005, Institutional trading and share returns, SSRN eLibrary.

Gallagher, David R., Peter Gardner, and Peter L. Swan, 2009, The threat of exit with optimal contracting: Institutional churning trades and subsequent firm performance, SSRN eLibrary.

Galariotis, Emilios C., 2010, What should we know about momentum investing? The case of the Australian Security Exchange, Pacific-Basin Finance Journal 18, 369-389.

Gaunt, Clive, 2004, Size and book to market effects and the fama french three factor asset pricing model: Evidence from the australian stockmarket, Accounting \& Finance 44, 27-44.

Gaunt, Clive, and Philip Gray, 2003, Short-term autocorrelation in australian equities, Australian Journal of Management 28, 97-118. 
Griffin, John M., Xiuqing Ji, and J. Spencer Martin, 2003, Momentum investing and business cycle risk: Evidence from pole to pole, Journal of Finance 58, 2515-2547.

Grinblatt, Mark, Sheridan Titman, and Russ Wermers, 1995, Momentum investment strategies, portfolio performance, and herding: A study of mutual fund behavior, The American Economic Review 85, 1088-1105.

Grundy, Bruce D., and J. Spencer Martin, 2001, Understanding the nature of the risks and the source of the rewards to momentum investing, The Review of Financial Studies 14, 29-78.

Halliwell, Jason, Richard Heaney, and Julia Sawicki, 1999, Size and book to market effects in australian share markets: A time series analysis, Accounting Research Journal 12, 122-137.

Henker, Thomas, Martin P. Martens, and Robert Huynh, 2006, The vanishing abnormal returns of momentum strategies and 'front-running' momentum strategies, SSRN eLibrary.

Heston, Steven L ., and K. Geert Rouwenhorst, 1995, Industry and country effects in international stock returns, The Journal of Portfolio Management 21, 53-58.

Hurn, Stan, and Vlad Pavlov, 2003, Momentum in australian stock returns, Australian Journal of Management 28, 141-155.

Jegadeesh, Narasimhan, 1990, Evidence of predictable behavior of security returns, The Journal of Finance 45, 881-898.

Jegadeesh, Narasimhan, and Sheridan Titman, 1993, Returns to buying winners and selling losers: Implications for stock market efficiency, The Journal of Finance 48.

Jegadeesh, Narasimhan, and Sheridan Titman, 2001, Profitability of momentum strategies: An evaluation of alternative explanations, The Journal of Finance 56, 699-720.

Jegadeesh, Narasimhan, and Sheridan Titman, 2002, Cross-sectional and time-series determinants of momentum returns, The Review of Financial Studies 15, 143-157.

Kassimatis, K., 2008, Size, book to market and momentum effects in the australian stock market, Australian Journal of Management 33, 145-168. 
Keim, Donald B., and Ananth Madhavan, 1997, Transactions costs and investment style: An interexchange analysis of institutional equity trades, Journal of Financial Economics 46, 265-292.

Korajczyk, A. Robert, and Ronnie Sadka, 2004, Are momentum profits robust to trading costs?, Journal of Finance 59, 1039-1082.

Lesmond, David A., Michael J. Schill, and Chunsheng Zhou, 2004, The illusory nature of momentum profits, Journal of Financial Economics 71, 349-380.

Lo, Andrew W., and A. Craig MacKinlay, 1990, Data-snooping biases in tests of financial asset pricing models, The Review of Financial Studies 3, 431-467.

Lo, Andrew W., and A. Craig MacKinlay, 1990, When are contrarian profits due to stock market overreaction?, The Review of Financial Studies 3, 175-205.

Moskowitz, Tobias J., and Mark Grinblatt, 1999, Do industries explain momentum?, The Journal of Finance 54, 1249-1290.

O'Brien, Michael A, Brailsford, Timothy J. and Gaunt, Clive, Size and book-to-market factors in Australia (August, 05 2008). 21st Australasian Finance and Banking Conference 2008 Paper. Available at SSRN: http://ssrn.com/abstract=1206542

Rouwenhorst, K. Geert, 1998, International momentum strategies, The Journal of Finance 53, 267-284.

Rouwenhorst, K. Geert, 1999, Local return factors and turnover in emerging stock markets, The Journal of Finance 54, 1439-1464.

Scowcroft, Alan, and James Sefton, 2005, Undestanding momentum, Financial Analysts Journal 61. 